\title{
XLV. Observations on the lotus of Egypt
}

\section{Alire Raffenau-Delile}

To cite this article: Alire Raffenau-Delile (1803) XLV. Observations on the lotus of Egypt , Philosophical Magazine Series 1, 15:59, 257-263, DOI: 10.1080/14786440308676267

To link to this article: http://dx.doi.org/10.1080/14786440308676267

$$
\text { 曲 Published online: } 18 \text { May } 2009 .
$$

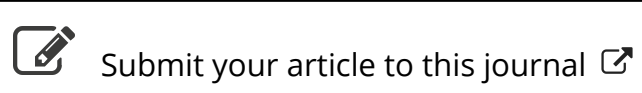

\footnotetext{
Џ Article views: 2
}

Q View related articles $₫$ 
that I have here given philofophers a further inducement to admire with me the great and noble operations of the divine providence, which fo evidently appear in the different changes effected in air and water, and which are fo neceffary for fupporting and maintaining the creation.

Groningen,

Febriary 26, 1 \{0\}:

\section{Obfervations on the Lotus of Fgypt. By ALIRT Rapfenau-Delte} SINCE my return from Eigypt I prefented to the Mufeum
of Natural Hiftory different kinds of feeds and feveral bulbs of the nymphaca carrulea, of which an accurate defcription was given in Egypt by C. Savigny, my colleague. Thefe bulbs begin to germinate-towards the end of Meffidor, when kept immerfed in water. I collected them in the ifland of Rofetta irr the month of Ventofe, year 8; and though I had kept them tivo years without planting them, they had not become deficcated: one of the plants of the nymphra has already produced fevera Jflowers fomewhat fmaller, lefs odorous, and of a paler blue colour, than thofe in Egypt.

Though I made a tour with the Commiffion of Arts into Upper Egypt during the time of the inundation, which is that allo of the increafe of the two kinds of nymphra of the Nile, we met with none of thefe plants in that country.

The waters of the Nile rife to a confiderable height in the Said, and much lefs in Lower Egypt. The nymphæa, therefore, eafily reaches the furface of the water, during the inundation, in the lakes and the canals of the Delta, where they are not hurt by the current of the river. It is, perhaps, for a contrary reafon that the nymphra does not grow in the Said.

We obferved the nymphæa cærulea painted and engraven on the Egyptian monuments much oftener than the two kinds of totus mentioned by the oldeft hiftorians. This nymphra has a great refemblance to thefe kinds of lotus, and appears to be a third fpecies of it.

Moft authors who have undertaken to make known the lotus in regard to its antiquity have fallen into many errors; but Mahudel, of the Academy of Inferiptions and Belles

\footnotetext{
* From Annales du Mafeam National d' Hifoire Nuturelle, Nr. 5. VoL. XV. No. 59 . 
Lettres *, and lately profeffor Sprengel, of Halle $\dagger$, have given very accurate information refpecting thefe plants.

The expedition to Egypt afforded me an opportunity of making the following oblervations on the fame fubject : they are naturally contrected with thofe already made in Egypt by C. Savigny on the nymphæa carulea, and complete the hiftory of that plant.

Herodotus $\ddagger$ relates that the Egyptians fed on the lotus which grew in the waters of the Nile. He calls this lotus a lily, and fays that the feeds, fimilar to thofe of the poppy, were employed for making bread. He adds, that they ate alfo the roots of the lotus, which were round, of the fize of an apple, and of a fweet and agreeable favour. Herodotus then fpeaks of another kind of lily refembling a rofe, which grew alfo in the Nile, the fruit of which had the form of a wafp's neft, and which contained feveral feeds good to eat, and of the fize of an olive.

Theophraftus $\S$ gives a very accurate defcription of the fame plants :- " The lotus," fays he, "grows in the fields when they are inundated. Its flowers are white, and have petals like thofe of the lily. They fpring up in great numbers clofe to each other. They thut their leaves at fun-fet, and conceal their fruit. Thefe flowers open again when the fun reappears, and rife above the water; and this alternation is repeated till the fruit is completely formed, and the flowers bave dropped off. The fruit is equal to that of a large poppy, and contains a great number of feeds fimilar to grains of millet. The Egyptians depofit the fruit in heaps, and fuffer the rind to putrefy ; they then feparate the feeds by wathing them in the Nile, dry them, and knead them into bread. The root of the lotus called corfion is round, and of the fize of a quince. Its rind is black, and like that of the cheftunt. This root is white in the infide, and is eaten either raw or boiled."

The lily of the Nile, like the rofes mentioned by Herodotus, is called by Athenæus \|f Egyptian bean, and the rofe lotus. Theophraftus gives it the name of bean.

"This bean grows in the marfhes and ponds. Its fem is four cubits in length, and as thick as the finger. It relembles a reed without knots. The fruit it bears is thaped like a wafp's neft, and contains about thirty beans a little prominent, each depofited in a different cell. The flower is twice as large as that of the poppy, and entirely a rofe. The leaves are fup-

\footnotetext{
* Hilloire de l'Academie des Infcriptions, vol. ii. p. 285.

+ Aniquitatum botanicarum Specimen prinum, p. 47.

In Eut:rpe, cap, xcii.

$\$$ Theophrafti Hift. Plant. lib. iv. cap. ro.

if Athenæi Deipnofoph. lib. iii. p. 72 ; lib. xv. p. 677.
} 
portèd by pedicles fimilar to thofe of fruits : they are large, and have a refemblance to a Theffalian cap. When one of the beans is bruifed there is feen in the infide of it a fmall body folded together, from which the leaf arifes. The root is thicker than that of a ftrong reed, and has partitions like the ftem. It ferves as nourifhment to thofe who refide near the marhes. This plant grows fpontaneounly, and in abundance. It is fown alfo in the mud, by forming for it a bed of ftraw, in order that it may not rot."

The lotus of Herodotus and Theophraftus grows alfo in Egypt. It is the nympbea lotus of Linnæus*, the characters of which, compared by C. Savigny to thofe of the ny'mpbcea carulea, agree with the defcriptions given by the antients.

In regard to the rofe lily or Egyptian bean; which is frequently carved out among the ornaments and fymbolical reprefentations of the Egyptian temples, it no longer grows in that country; and would have remained unknown to naturalifts had it not been difcovered in India. This plant has been called by Linnæus the nympbrea nelumbo. lit fruit, which the Greeks compare to a wafp's neft, has a perfect refemblance to it. They called it ciborion $\ddagger$ on account, no doubt, of its refemblance to a cup. This frut is thaped like the fpout of a watering-pot, and is flatted at the upper part, which contains from fiftecn to thirty fmall foffre, containing a like number of feeds of the fize of a nut, and fomewhat prominent. The plumula $\S$, which is the rudiment of the leaves, is, indeed, rolled up in the middle of the feed, as Theophraftus fays. The flowers are rofes, and very large. The leaves are orbicular, thuriform, and about two feet in diameter\|.

Belon has confounded the Egyptian bean with the colocafia o (arum colocafa Linn.), which is cultivated in Egypt: as the Greeks often gave the name of colscafic to the root of the Egyptian bean **, it was a difficult matter to avoid confounding the fe wo plants.

Sprengel reniarks, that the appellation of colocafia was given alfo to the nymplice lotus t+:

But we receive as much information refpecting thefe plants

* Speries Plantarum, P. 729.

+ Ibid. p. 730 .

+ Athenæi Deipnofoph. lib, iii. p. 72 ; \& lib.xi. p. 477. Diodorus Siculus, lib. i. Dulcorides, lib. ii. cap. 97 .

\& Gartner De Fruetibus, \&c. tom. i. p. 74. tab. Iq.

1) Hortus Malabar. tom. xi. p. 6I.

If Belon, Obfervations, lib, ii. chap. 28

* Athenai Deipnoloph. lib. iii. p. 72 \& 73 .

t† Antiquitat. botanic. Specimen prien. c. $8 \mathrm{~g}$. 
from antient fculptures as from the account of hiforians. The rofe lotus, or Egyptian bean, is very correetly reprefented in the mofaic of Paleftrine, an explanation of which has been given by Barthelemy in the Memoirs of the Academy of Infcriptions and Belles-Lettres*. The fruit, the flowers, and the leaves of that plant are exceedingly like. They foat on the furface of the water in a lake which carries feveral barks during the time of a feftival. This painting brings to remembrance a paffage of Strabot, who fays, that people made excurfions of pleafure in boats on the lakes covered with beans, and that they theltered themfelves from the fun with the leaves of that plant. On the Egyptian monuments Harpocrates is reprefented above the flower of the fruit of the rofe lotus. This plant, fo well known in antient Egypt, is at prefent celebrated in the religion of the Bramins, and is often placed among the attributes of the Indian deities $f$.

It is not poffible to fay to what kind of lotus the flowers feen reprefented on the heads of the Egyptian kings or deities in feveral medals belonged, becaufe the fpecies of lotus differ chiefly in regard to the colour of their flowers, and the form of their fruits or leaves; but on the walls of the temples of Egypt, and on the cafes containing the mummies, they may be eafily diftinguifhed when the painting is in good: prefervation. The Egyptians often reprefented the leaves of the white lotus (nympbeza lotus) of the fame fize as the flowers, thongh naturally the leaves are much larger; but they have omitted to mark the indentations of thefe leaves, which indeed are wanting when the plant is very young. I have, however, feen in the table of Latopolis this lotus reprefented with the leaves inclented.

But it would be in vain to feek for fcrupulous exactnefs in allegorical feulptures. Thus on the bafe of the ftatue of the Nile, placed in the gardens of the Tuileries, the fruit of the lotus is very exactly reprefented, but the leaves which accompany it are not thofe of that plant.

The fruit of the white lotus, which has the fame form as

* Hiftoire del'Acad, des lnfeript. 1790. The Pitiure anticbe di Pietre s. Barticoli, which reprefent the nofaic with its colours, may be feen in tive library of the Pantheon.

+ Strabo, lib. xvii. The Greek text has been badly interpreted by tranflators, who fuppofed that the boats rowed along under the fhade of the leives, which rote to a great height above the water. Thefe leaves float on the furface of the water, and are very broad. It appears that the boats were covered with them in order to form a thade, as they are covered in Egypt at prefent with the leaves of the date-tree and with reeds.

i Syttema Brahmanicum Fr. Paullinii, à Bartholom. tab. 9 \& 10. 
that of the poppy, may be difinguifhed on the Egyptian monuments. In my opinion, this refemblance has made the fruit of the lotus, delineated on feveral Egyptian medals, to be confounded with that of the poppy. The frtits reprefented on thefe medals are the fame as thofe feulptured on the Egyptian monuments anterior to thofe of the Greeks. It does not appear from any hiftorical teftimony that the Egyptians ever made much ufe of the poppy; and they rather placed the fruits of the lotus among the attributes of Ifs, with ears of corn, as a fign of abundance and fertility, finoe they were long accuftomed to make a fort of bread with the feeds of that plant. The Egyptian lotus was very little known to the Greeks and the Romans, who compared it to the molt common plants. Herodotus calls the lotus a lily; Theophraftus compared it to the poppy, and Pliny calls its flowers poppies*. Another caufe which may have occafioned the lotus to be confounded with the poppy, is the refemblance which exifts between the attributes of Ifis and thofe of Ceres, to whom the poppy was confecrated + .

The nymphea lotus and the nympbea nelumbo are the two fpecies of lotus defcribed by Herodotus and Theophraftus. Both grew naturally in Egypt, and were cultivated in that country. It was the fruit of the cultivated nympboa lotus to which Pliny gives the name of lotometra $\neq$.

A paffage in Athenæus proves that the nympiosa crerulea is a third fpecies of lotus. This author relates that Antinoian $\S$ crowns were made at Alexandria with the rofe lotus, and that the blue were interwoven with thefe crowns. The flowers of thefe different kinds of lotus are very odoriferous, have great fplendour and frefhnefs, and muft have been $f_{e-}$ lected for making crowns. Heliodorus relates, that couriers who announced a victory in Meroe were crowned with lotus $\|$. When Plutarch fpeaks of a crown of melitot which fell from the head of OGris $q$, and when he claffes that plant among thofe which grow in the Nile, he alludes to a crown of lotus. Athenæus relates, that the lotus was alfo called melilot **, and that it was formed into melilotine garlands. The fame hiftorian tells us alfo why the rofe lotus was called the Antinoian. A poet prefented the emperor Adrian, during

* Plin. Hit, Nat. lib. xiii. cap. 17.

+ Virgil. Georg, i, ver, 2 I 2 . Ovid, Faft. lib. iv. Theoc. Idyll, vii, ver. 153. Callimach. Hymn, Cer, ver: 45 ,

$\$$ Plin. Hift. Nat. lib, xxii, cap. $2 \neq$.

$\$$ Athenxi Deipnofoph. lib. xv, p. 677 .

il Heliodor. Ethiog. Lib. x. cap. 28.

7 Treatife on Ifis and Ofiris.

* Athenai Deipnoroph. lib. iii. p. 73. 
his refidence at Alexandria, with a rofe lotus as a rarity, and faid that this lotus, which had grown up in a country moiftened by the blood of fo terrible a lion, ought to be called the Antinoian. The lion of which the poet here fpeaks had ravaged a part of Libya, and had at length been deftroyed by the emperor Adrian during a hunting excurfion.

Independently of the plaufible conjectures of feveral writers refpecting the origin of the religious employment which the Egyptians made of the lotus, thefe plants, on account of their fimple and natural properties, muft have been very much celebrated in antient Egypt. This country being indebted to the Nile for its profperity, its inhabitants confidered as the figns of a great benefit the plants which grew in the waters of that river. The flowers of the lotus rife to the furface of the water when the Nile begins to increafe, and announce the inundation, which is about to bring abundance along with it. Belides the names of bacbenin and naufar, which the Eguptians give to the nymphæa, they call them alfo araïs el Nil, that is to fay, wbich grow up in the Nile. Thefe names certainly refer to the fertility about to be renewed by the prefence of the waters.

The Egyptians collected the roots of the lotus when the waters of the Nile retired. At prefent they are feldom collected; but they multiply very much in the rice-fields, fo that the peafants are obliged to pull them up after the rice harveft. They then fometimes eat thefe roots, which they call biaro. I faw fome of them fold in the market of Damietta in the month of Frimaire, year $7:$ I tafted them, and found that their tafte was not difagreeable. Thefe roots are round, or fomewhat oblong, and fmaller than a common egg. The rind is black, and coriaceous : thev exhibit tubercles, traced out by the bafe of the petioles or fhoots. -Thefe roots in the infide are white and farinaceous; in the centre they are yellowifh. After the inundation they remain funk in the earth which has becomedry; and the following year, when covered by water, they fend forth leaves and fmall roots merely from the fummit, which has a cottony appearance. The radicula penetrate laterally into the mud, where they produce tubercles which become fimilar to the former roots, and which multiply the plant. The Egyptians to collect the feeds wathed them, after leaving the rind of the fruit to putrefy. This method is the only one that could be employed, otherwife thefe feeds would bicome mixed and deficcated with the parcnchyme of the fruit. Thefe feeds are very fnall, sofe-coloured or gray on the outfide, and farinaceous within. The antients compared them to grains of nillet. I have 
heard the peafants call them dochn el bacbening, that is to fay, millet of bachenin : but they told me that they were of yery little ufe. The roots and feeds of the nympbcea lotus and thofe of the nympbrea carulen are fimilar. It is natural, then, to believe that the Egyptians not only made garlands of the blue lotus, but that they ufed it for food like the nympbara lotus. This is proved by the Egyptian fculptures, fince the blue nymphæa is often reprefented among the offerings of fruits in the grottos of Said, the paintings of which exhibit fcenes of domeftic life.

Of the two kinds of nymphæa, the Egyptians at prefent prefer that with blue flowers, which is often reprefented in the temples. Ebn il Bitar, an Arabian phyfician, who has written a treatife on plants, quoted by Profper Alpinus *, diftinguifhes two kinds of bacbenin or nympbcea, the beft of which is called that of the Arabs. I obferved that the peafants of the Delta gave the nanie of bachenin of the Arabs to the nympbaa corulea, and that they fet lefs value on the nympbea lotus.

As the antients have made very little mention of the blue lotus, one might believe that it was brought to Egypt from the Eaft Indies along with the rice, fince it grows abundantly in the rice-fields of the Delta; but the paintings in the temples evidently prove that this plant is as antient in Egypt as the nympbaa lotus.

It is certain that the nympbac carulea exifts in India. In the Hortus Malabaricus it is called citambel + . Rumphius confiders it as a variety with blue flowers of the nympbea lotus $\ddagger_{-}$. This nymphea grows allo at the Cape of Good Hope, and feems to be fufficiently diftinguifhed by the following phrafe of Breyn: nympbeea flore cariuleo odoratiffimo Capitis Bonce Spei \$. A figure of it has been given by An. drews $\|$.

* Profperi Alpini Rerum Egypt. lib. iii. cap. 10.

+ Tom. ii. p. 53. táb. 27 .

+ Herbar. Amboin. tom. vi. p. 72.

$\S$ Prodrom. ii. 26.

(I) Botanifts Repofitory, 197 . 